\title{
Effects of VEGF and VEGFR polymorphisms on the outcome of patients with metastatic renal cell carcinoma treated with sunitinib: a systematic review and meta-analysis
}

Keywords: VEGF/VEGFR, polymorphisms, metastatic renal cell carcinoma, sunitinib, meta-analysis

Received: July 11, $2017 \quad$ Accepted: July 26, $2017 \quad$ Published: August 04, 2017

Copyright: Miao et al. This is an open-access article distributed under the terms of the Creative Commons Attribution License 3.0 (CC BY 3.0 ), which permits unrestricted use, distribution, and reproduction in any medium, provided the original author and source are credited.

\section{ABSTRACT}

To summarize and clarify the association between vascular endothelial growth factor (VEGF) and vascular endothelial growth factor receptor (VEGFR) polymorphisms and the outcome in patients with metastatic renal cell carcinoma ( $\mathrm{MRCC}$ ) treated with sunitinib. A total of $\mathbf{8}$ studies including $\mathbf{9 0 0}$ patients were analyzed in this systematic review after screening the database of PubMed, EMBASE and Web of Science. Hazard ratios (HRs) with $95 \%$ confidence interval (CI) were used to evaluate the strength of the association. VEGFR1 rs9582036 AA/AC carriers and rs9554320 CC/AC carriers had more favorable overall survival (OS) in patients with mRCC treated with sunitinib $(n=3)$, but not in progression-free survival (PFS). In addition, VEGFA rs2010963 was associated with poorer PFS of $\operatorname{mRCC}(n=1)$. VEGFA rs699947 was significant in predicting PFS by univariate analysis, but showed no statistical significance in OS $(n=1)$. VEGFR2 rs1870377 was verified to be associated with sunitinib OS $(n=1)$. Furthermore, patients with VEGFR3 rs307826 and rs307821 had shorter PFS and OS during sunitinib therapy ( $n=2$, respectively). Our results suggested that VEGF and VEGFR polymorphisms were associated with outcomes in sunitinib treated mRCC patients, especially VEGFR1 polymorphisms. However, considering the limited study numbers, its clinical application in sunitinib treated mRCC still needs further confirmation.

\section{INTRODUCTION}

Renal cell carcinoma (RCC) is the seventh most common cancer in males and the ninth most common cancer in females, and accounts for nearly $2 \%$ of all malignant diseases in adults [1]. Besides, the initial clinical course of RCC is asymptomatic, resulting in $25-30 \%$ of patients presenting with metastatic disease when diagnosed [2]. Several molecular-targeted drugs have emerged as the first-line treatment for mRCC patients attributed to its insensitivity to chemotherapy and radiotherapy [3-6]. Sunitinib, as a small-molecule receptor tyrosine kinase inhibitor (TKI), gaining the approval of the Food and Drug Administration (FDA) in 2006. Sunitinib has now been considered as the first-line therapy of mRCC contributed by its anti-angiogenic and anti-tumor activity $[7,8]$. Although sunitinib treatment was verified to extend mRCC patients' survival, accumulating investigations have reported that its effects on outcome might be relevant to specific gene single-nucleotide polymorphisms (SNPs) [9-17]. It has been confirmed that SNPs might connect with pharmacokinetics and pharmacodynamics of sunitinib, thus affecting the prognosis of mRCC patients. However, controversial findings still existed and the conclusion could hardly reach a consensus.

Vascular endothelial growth factor (VEGF) is a potent endothelial cell mitogen that exerts a crucial role in angiogenesis $[18,19]$. The VEGF receptors (VEGFR1, 
VEGFR2 and VEGFR3) also play a significant role in the signaling pathways involved in RCC pathogenesis, and mutations in VEGFRs may affect the signaling networks [20]. Currently, the therapeutic strongholds for metastatic renal cell carcinoma (mRCC) are mostly represented by tyrosine-kinase inhibitors (TKIs) directed against the vascular endothelial growth factor (VEGF) signaling pathway. One of these new molecules, approved for first-line mRCC treatment, is sunitinib [21, 22]. However, previous findings indicated the effective rate was only $60-75 \%$, leaving quite a number of patients to undergo ineffective treatment with added secondary adverse reactions [23].

Therefore, it is really crucial to find appropriate biomarkers closely linked to the clinical outcome in patients with metastatic renal cell carcinoma treated with sunitinib. Recently, several researches focusing on the association between $V E G F$ and $V E G F R$ polymorphisms and outcome in patients with $\mathrm{mRCC}$ treated with sunitinib indicated that some of gene SNPs had significant associations with the survival, while some articles not. Therefore, this systematic review and meta-analysis aimed to conduct an overview of relevant studies, and obtain more comprehensive correlation of $V E G F$ and $V E G F R$ polymorphisms with the outcome of $\mathrm{mRCC}$ patients treated with sunitinib.

\section{RESULTS}

\section{Characteristics of included studies}

8 relevant studies were ultimately enrolled in this systematic review, including 900 patients (635 male and 265 female). Seven eligible studies were performed in Caucasian population except one in Asian. Among the 8 studies, 3 studies reported the correlation of VEGFA polymorphisms with patients' outcome undergoing sunitinib treatment, 3 studies reported VEGFR1, 3 focused on VEGFR2 and 6 investigated VEGFR3. In addition, genotyping method, analysis method and metastatic sites were also collected. The detailed summaries of included studies were presented in Table 1. All patients of eligible studies were verified with metastatic RCC and metastases were present in the following organs: lung, liver, bone, brain, lymph nodes, kidney and others. Sunitinib was used as the first line therapy in the treatment of $\mathrm{mRCC}$ patients from included investigations. Among these studies, detected gene polymorphisms consisted of VEGFA (rs2010963, rs699947, rs1570360), VEGFR1 (rs9582036, rs9554320), VEGFR2 (rs1870377) and VEGFR3 (rs307826, rs448012, rs307821). Besides, the survival data including PFS and OS were extracted from available articles and the following up duration was also recorded. Further information was exhibited entirely in Table 2 and Table 3.

\section{VEGFA polymorphisms associated with outcome}

Three researches involving VEGFA rs2010963 are listed in Table 2. In the research conducted by Garcia-
Donas et al. in 2011, VEGFA rs2010963 polymorphism shows no statistical association with PFS and OS of the mRCC patients received sunitinib, same as that conducted by Dornbusch et al. in 2016 [15, 16]. However, only Scartozzi et al. in 2013 found that PFS proved statistically significance for CG vs GG (HR: 3.34, 95\% CI: 1.19-9.38), and CC vs GG (HR: 15.77, 95\% CI: 3.11-79.92) (Table 2) [17]. Besides, researches designed by Garcia-Donas et al. in 2011 and Dornbusch et al. in 2016 indicated that VEGFA rs699947 was not significantly associated with the PFS and OS of the patients in multivariate analysis [15, 16]. Nevertheless, Dornbusch et al. reported a significant correlation between rs699947 and PFS in univariate analysis (HR: 0.535, 95\% CI: 0.317-0.904) (Table 2) [15]. Furthermore, two studies investigating VEGFA rs1570360 exerted no obvious results in both PFS and OS of mRCC patients.

\section{VEGFR1 polymorphisms associated with outcome}

Patients with VEGFR1 rs9582036 AA/AC carriers had superior OS after sunitinib receiving with a pooled HR of 0.29 (95\% CI: 0.17-0.47), and rs9554320 with $\mathrm{CC} / \mathrm{AC}$ carriers also predicted favorable OS (HR: 0.55, 95\% CI: 0.38-0.78), but not in patients' PFS (Figure 1). In addition, Beuselinck's research in 2014 showed that VEGFR1 rs9582036 had a significant association with the OS of mRCC patients (HR: 0.2493, 95\% CI: $0.07778-$ 0.7992) (Table 3) [14]. Beuselinck et al. in 2016 found rs9582036 and rs9554320 was significant in PFS in both multivariate and univariate analysis (Table 3) [13]. What's more, in Beuselinck's study, mRCC patients with the AAvariant in VEGFR1 rs9554320 have a poorer OS (HR: 2.286, 95\% CI: 1.147-4.555) (Table 3). Dornbusch et al., however, did not find any significant association between VEGFR1 rs9554320 and OS of the patients, PFS either (Table 3) [15].

\section{VEGFR2 polymorphisms associated with outcome}

Among three studies concentrating on effects of VEGFR2 polymorphism on survival, Liu's study in 2017 reported AA-variant in rs1870377 predicted poorer OS in $\mathrm{mRCC}$ patients (HR: 3.526, 95\% CI: 2.852-5.629) (Table 3) [24]. Moreover, other two researches failed to found any significant differences (Table 3) $[15,16]$.

\section{VEGFR3 polymorphisms associated with outcome}

As it came to VEGFR3 rs307826, there turned up divergences between the different researchers. Four researches concerning this SNP were carried out respectively by Garcia-Donas et al. in 2011, Beuselinck et al. in 2013, Motzer et al. in 2014 and Dornbusch et al. in 
Table 1: Main characteristics of included studies in the systematic review and meta-analysis

\begin{tabular}{|c|c|c|c|c|c|c|c|c|c|c|c|}
\hline \multirow{2}{*}{ First author,year } & \multirow{2}{*}{ Age } & \multirow{2}{*}{$\begin{array}{c}\text { Main } \\
\text { Ethnicity }\end{array}$} & \multirow{2}{*}{$\begin{array}{l}\text { Sample } \\
\text { size }\end{array}$} & \multicolumn{2}{|c|}{ Gender } & \multirow{2}{*}{ Gene SNPs } & \multirow{2}{*}{ Genotyping method } & \multirow{2}{*}{ Site of metastasis } & \multirow{2}{*}{$\begin{array}{l}\text { Survival } \\
\text { analysis }\end{array}$} & \multirow{2}{*}{$\begin{array}{l}\text { Source } \\
\text { of HR }\end{array}$} & \multirow{2}{*}{ Follow-up time (month) } \\
\hline & & & & Male & Female & & & & & & \\
\hline Liu, 2017 & $62.3(46-72)$ & Asian & 68 & 40 & 28 & VEGFR2/VEGFR3 & PCR-RFLPs & $\begin{array}{l}\text { Lung/Lymphatic/ } \\
\text { Osseous/Hepatic/ } \\
\text { Adrenal/Other }\end{array}$ & OS & Reported & median 15 (6-23) \\
\hline Dornbusch, 2016 & $59(53.5-67.0)$ & Caucasian & 121 & 95 & 26 & $\begin{array}{l}\text { VEGFA/VEGFR1/ } \\
\text { VEGFR2/VEGFR3 }\end{array}$ & TaqMan & NA & $\mathrm{PFS} / \mathrm{OS}$ & Reported & median $24.6(10.5-41.6)$ \\
\hline Beuselinck, 2016 & 59 & Caucasian & 157 & 113 & 44 & VEGFRI & $\begin{array}{c}\text { Sequenom } \\
\text { MassArray platform }\end{array}$ & $\begin{array}{c}\text { Lung/Liver/Bone/ } \\
\text { Brain }\end{array}$ & $\mathrm{PFS} / \mathrm{OS}$ & Reported & median $77(1-116)$ \\
\hline Motzer, 2014 & NA & Caucasian & 202 & 135 & 67 & VEGFR3 & TaqMan & $\mathrm{NA}$ & PFS & Reported & NA \\
\hline Beuselinck, 2014 & 59 & Caucasian & 91 & 62 & 29 & VEGFRI & $\begin{array}{c}\text { Sequenom } \\
\text { MassArray platform }\end{array}$ & $\begin{array}{c}\text { Lung/Liver/Bone/ } \\
\text { Brain }\end{array}$ & OS & Reported & median $50(1-75)$ \\
\hline Beuselinck, 2013 & $59(38-84)$ & Caucasian & 88 & 60 & 28 & VEGFR3 & $\begin{array}{c}\text { Sequenom } \\
\text { MassArray platform }\end{array}$ & $\begin{array}{c}\text { Lung/Liver/Bone/ } \\
\text { Brain }\end{array}$ & $\mathrm{PFS} / \mathrm{OS}$ & Reported & median $46(1-73)$ \\
\hline Scartozzi, 2013 & $64(47-85)$ & Caucasian & 84 & 65 & 19 & $V E G F A / V E G F R 3$ & TaqMan & NA & PFS & $\mathrm{SC}$ & maximum $42 / \mathrm{SC}$ \\
\hline Garcia-Donas, 2011 & $65(42-87)$ & Caucasian & 89 & 65 & 24 & $\begin{array}{c}\text { VEGFA/VEGFR2/ } \\
\text { VEGFR3 }\end{array}$ & $\begin{array}{c}\text { KASPar SNP } \\
\text { genotyping system }\end{array}$ & $\begin{array}{l}\text { Lung/Lymph nodes/ } \\
\text { Bone/Kidney/Liver }\end{array}$ & $\mathrm{PFS} / \mathrm{OS}$ & Reported & median $21.2(8.4-25.6)$ \\
\hline
\end{tabular}

SNPs, single-nucleotide polymorphisms; VEGFA, vascular endothelial growth factor A; VEGFR, vascular endothelial growth factor receptor; OS, overall survival; PFS, progressionfree survival.

NA, not available; SC, survival curve.

Table 2: Association between $V E G F A$ polymorphisms and sunitinib outcome in $\mathrm{mRCC}$

\begin{tabular}{|c|c|c|c|c|c|c|c|}
\hline Gene SNPs & First author, year & Allele/Genotype & PFS HR (95\% CI) & $P$ value & OS HR ( $95 \%$ CI) & $P$ value & Analysis method \\
\hline \multirow[t]{4}{*}{$\begin{array}{l}V E G F A \\
\mathrm{rs} 2010963(\mathrm{G}>\mathrm{C})\end{array}$} & Dornbusch, 2016 & $\mathrm{CC}+\mathrm{CG}$ vs $\mathrm{GG}$ & $\begin{array}{l}0.615(0.357-1.061) \mathrm{M} \\
0.683(0.463-1.008) \mathrm{U}\end{array}$ & $0.08 \mathrm{M} 0.055 \mathrm{U}$ & $\begin{array}{c}0.751(0.354-1.593) \mathrm{M} \\
0.687(0.403-1.173) \mathrm{U}\end{array}$ & $0.455 \mathrm{M} 0.169 \mathrm{U}$ & $\mathrm{M} / \mathrm{U}$ \\
\hline & Scartozzi, 2013 & CG vs GG & 3.34 (1.19-9.38) U & $<0.05 \mathrm{U}$ & NA & NA & M \\
\hline & Scartozzi, 2013 & $\mathrm{CC}$ vs GG & $15.77(3.11-79.92) \mathrm{U}$ & $<0.05 \mathrm{U}$ & NA & NA & M \\
\hline & Garcia-Donas, 2011 & $\mathrm{CC}$ vs GG & $0.96(0.62-1.49) \mathrm{M}$ & 0.86 & $1.08(0.59-1.96) \mathrm{M}$ & 0.8 & M \\
\hline \multirow[t]{2}{*}{$\begin{array}{l}V E G F A \\
\text { rs699947 (A>C) }\end{array}$} & Dornbusch, 2016 & $\mathrm{CC}+\mathrm{AC}$ vs $\mathrm{AA}$ & $\begin{array}{l}1.029(0.496-2.135) \mathrm{M} \\
\mathbf{0 . 5 3 5}(\mathbf{0 . 3 1 7 - 0 . 9 0 4 )} \mathrm{U}\end{array}$ & $\begin{array}{l}0.939 \mathrm{M} \\
\mathbf{0 . 0 1 9} \mathbf{U}\end{array}$ & $\begin{array}{l}0.626(0.256-1.531) \mathrm{M} \\
0.614(0.316-1.192) \mathrm{U}\end{array}$ & $0.304 \mathrm{M} 0.149 \mathrm{U}$ & $\mathrm{M} / \mathrm{U}$ \\
\hline & Garcia-Donas, 2011 & CC vs AA & $1.01(0.68-1.51) \mathrm{M}$ & $0.96 \mathrm{M}$ & $0.72(0.40-1.27) \mathrm{M}$ & $0.25 \mathrm{M}$ & M \\
\hline \multirow[t]{2}{*}{$\begin{array}{l}\text { VEGFA } \\
\text { rs } 1570360(\mathrm{G}>A)\end{array}$} & Dornbusch, 2016 & $\mathrm{AA}+\mathrm{AG}$ vs GG & $\begin{array}{l}0.981(0.616-1.563) \mathrm{M} \\
1.087(0.741-1.595) \mathrm{U}\end{array}$ & $\begin{array}{l}0.936 \mathrm{M} \\
0.670 \mathrm{U}\end{array}$ & $\begin{array}{l}0.757(0.406-1.410) \mathrm{M} \\
0.884(0.520-1.502) \mathrm{U}\end{array}$ & $0.380 \mathrm{M} \quad 0.649 \mathrm{U}$ & $\mathrm{M} / \mathrm{U}$ \\
\hline & Garcia-Donas, 2011 & AA vs GG & $1.13(0.75-1.70) \mathrm{M}$ & $0.56 \mathrm{M}$ & $0.79(0.44-1.44) \mathrm{M}$ & $0.44 \mathrm{M}$ & M \\
\hline
\end{tabular}

The source of HR and $95 \%$ CI was extracted from survival curves or article reports.

HRs, hazard ratios; $95 \%$ CI, 95\% confidence interval; $\mathrm{M}$, multivariate analysis; $\mathrm{U}$, univariate analysis.

SNPs, single-nucleotide polymorphisms; VEGFA, vascular endothelial growth factor A; VEGFR, vascular endothelial growth factor receptor; OS, overall survival; PFS, progression-free survival.

2016. Garcia-Donas found that rs307826 was significantly associated with PFS of the patients (HR: $3.57,95 \% \mathrm{CI}$ : 1.75-7.30), while other studies not (Table 3) [16]. What's more, Beuselinck's study indicated that there was a significant correlation between rs307826 and OS of the patients with a HR of 2.223 (95\% CI: 1.187-4.163), while other researchers found no discrepancy (Table 3) $[15,16$, 25, 26]. Furthermore, both Liu et al. and Garcia-Donas et al. studied the relationship of VEGFR 3 rs 448012 and the outcome of $\mathrm{mRCC}$ patients received sunitinib. They found no statistically significant association between the two in either PFS or OS (Table 3) [16, 24]. As well, data of three studies involving VEGFR 3 rs307821 were also summarized. Garcia-Donas et al. found that rs307821 was associated with PFS of the patients (HR: 3.31, 95\% CI: 1.64-6.68), and Beuselinck's research in 2013 arrived at the same result (HR: 1.981, 95\% CI: 1.060-3.702) (Table 3) $[16,25]$. As regarding the OS, only Beuselinck's study in 2013 indicated a significant association between
VEGFR 3 rs307821 and OS of mRCC patients (HR: 2.265, 95\% CI: 1.202-4.268), while other two studies found no statistically correlation (Table 3$)[15,16,25]$.

\section{Publication bias}

Begg's test and Egger's test were used to assess the publication bias in this meta-analysis. The Begg's funnel plots with pseudo $95 \%$ CIs were symmetric in the pooled analyses (Figures 2A and 2B). $P$ values from Egger's test were larger than 0.05 , which indicated no obvious publication bias in the meta-analysis.

\section{Sensitivity analyses}

Sensitivity analysis was performed by Stata 12.0 software to evaluated whether individual studies affected the pooled results. Analyses from fixed-effects model indicated that our results are reliable (Figures 3A and 3B). 
Table 3: Association between VEGFR polymorphisms and sunitinib outcome in mRCC

\begin{tabular}{|c|c|c|c|c|c|c|c|}
\hline Gene SNPs & First author, year & Allele/Genotype & PFS HR $(95 \%$ CI $)$ & $P$ value & OS HR $(95 \% \mathrm{CI})$ & $P$ value & $\begin{array}{l}\text { Analysis } \\
\text { method }\end{array}$ \\
\hline \multirow[t]{3}{*}{$\begin{array}{c}\text { VEGFRI } \\
\text { rs9582036 }(\mathrm{A}>\mathrm{C})\end{array}$} & Dornbusch, 2016 & $\mathrm{AA}+\mathrm{AC}$ vs $\mathrm{CC}$ & $\begin{array}{l}0.550(0.197-1.533) \mathrm{M} \\
0.721(0.362-1.434) \mathrm{U}\end{array}$ & $0.253 \mathrm{M} 0.351 \mathrm{U}$ & $\begin{array}{l}0.294(0.092-0.938) \mathrm{M} \\
0.294(0.128-0.676) \mathrm{U}\end{array}$ & $0.039 \mathrm{M} 0.004 \mathrm{U}$ & $\mathrm{M} / \mathrm{U}$ \\
\hline & Beuselinck, 2016 & $\mathrm{AA}+\mathrm{AC}$ vs $\mathrm{CC}$ & $\begin{array}{c}0.404(0.213-0.767) \mathrm{M} \\
0.25(0.10-0.63) U\end{array}$ & $0.0056 \mathrm{M} 0.003 \mathrm{U}$ & $\begin{array}{c}0.298(0.159-0.559) \mathrm{M} \\
0.18(0.07-0.47) U\end{array}$ & $0.0002 \mathrm{M} 0.0004 \mathrm{U}$ & $\mathrm{M} / \mathrm{U}$ \\
\hline & Beuselinck, 2014 & $\mathrm{AA}+\mathrm{AC}$ vs $\mathrm{CC}$ & NA & NA & $0.2493(0.07778-0.7992) \mathrm{M}$ & $0.008 \mathrm{M}$ & M \\
\hline \multirow[t]{3}{*}{$\begin{array}{c}\text { VEGFRI } \\
\text { rs } 9554320(\mathrm{C}>\mathrm{A})\end{array}$} & Dornbusch, 2016 & $\mathrm{CC}+\mathrm{AC}$ vs $\mathrm{AA}$ & $\begin{array}{l}1.454(0.688-3.070) \mathrm{M} \\
1.107(0.672-1.823) \mathrm{U}\end{array}$ & $0.327 \mathrm{M} 0.690 \mathrm{U}$ & $\begin{array}{l}1.233(0.504-3.015) \mathrm{M} \\
0.959(0.504-1.825) \mathrm{U}\end{array}$ & $0.646 \mathrm{M} 0.899 \mathrm{U}$ & $\mathrm{M} / \mathrm{U}$ \\
\hline & Beuselinck, 2016 & $\mathrm{CC}+\mathrm{AC}$ vs $\mathrm{AA}$ & $\begin{array}{c}0.486(0.299-0.787) M \\
0.33(0.18-0.62) U\end{array}$ & $\mathbf{0 . 0 0 3 4} \mathrm{M} 0.0005 \mathrm{U}$ & $\begin{array}{c}0.488(0.306-0.775) M \\
0.38(0.21-0.67) U\end{array}$ & $0.0024 \mathrm{M} 0.0009 \mathrm{U}$ & $\mathrm{M} / \mathrm{U}$ \\
\hline & Beuselinck, 2014 & $\mathrm{CC}+\mathrm{AC}$ vs $\mathrm{AA}$ & NA & NA & $0.437(0.220-0.872) \mathrm{M}$ & $0.067 \mathrm{M} 0.019 \mathrm{U}$ & $\mathrm{M}$ \\
\hline \multirow[t]{3}{*}{$\begin{array}{c}V E G F R 2 \\
\text { rs } 1870377(\mathrm{~T}>\mathrm{A})\end{array}$} & Liu, 2017 & AA vs TT & NA & NA & $3.526(2.852-5.629) \mathrm{U}$ & $<0.001 \mathrm{U}$ & $\mathrm{U}$ \\
\hline & Dornbusch, 2016 & $\mathrm{AA}+\mathrm{AT}$ vs $\mathrm{TT}$ & $\begin{array}{l}1.005(0.620-1.630) \mathrm{M} \\
0.929(0.626-1.378) \mathrm{U}\end{array}$ & $0.984 \mathrm{M} 0.714 \mathrm{U}$ & $\begin{array}{l}0.799(0.428-1.494) \mathrm{M} \\
0.807(0.467-1.393) \mathrm{U}\end{array}$ & $0.482 \mathrm{M} \quad 0.441 \mathrm{U}$ & $\mathrm{M} / \mathrm{U}$ \\
\hline & Garcia-Donas, 2011 & AA vs TT & $1.09(0.68-1.74) \mathrm{M}$ & $0.71 \mathrm{M}$ & $1.74(0.91-3.32) \mathrm{M}$ & $0.092 \mathrm{M}$ & M \\
\hline \multirow[t]{4}{*}{$\begin{array}{c}\text { VEGFR3 } \\
\text { rs307826 }(\mathrm{A}>\mathrm{G})\end{array}$} & Dornbusch, 2016 & $\mathrm{GG}+\mathrm{GA}$ vs $\mathrm{AA}$ & $\begin{array}{l}0.460(0.125-1.694) \mathrm{M} \\
0.645(0.382-1.088) \mathrm{U}\end{array}$ & $0.243 \mathrm{M} 0.100 \mathrm{U}$ & $\begin{array}{l}0.907(0.150-5.481) \mathrm{M} \\
1.245(0.640-2.419) \mathrm{U}\end{array}$ & $0.915 \mathrm{M} 0.519 \mathrm{U}$ & $\mathrm{M} / \mathrm{U}$ \\
\hline & Motzer, 2014 & GG vs AA & $0.94(0.23-3.81) \mathrm{U}$ & $0.929 \mathrm{U}$ & NA & NA & U/NA \\
\hline & Beuselinck,2013 & $\mathrm{GG}+\mathrm{GA}$ vs $\mathrm{AA}$ & $1.800(0.996-3.250) \mathrm{M}$ & $0.051 \mathrm{M}$ & $2.223(1.187-4.163) \mathrm{M}$ & $0.013 \mathrm{M}$ & M \\
\hline & Garcia-Donas, 2011 & GG vs AA & $3.57(1.75-7.30) \mathrm{M}$ & $0.0079 \mathrm{M}$ & $1.77(0.65-4.84) \mathrm{M}$ & $0.26 \mathrm{M}$ & M \\
\hline \multirow[t]{2}{*}{$\begin{array}{c}\text { VEGFR3 } \\
\text { rs448012 }(\mathrm{C}>\mathrm{G})\end{array}$} & Liu, 2017 & CC vs GG & NA & NA & $4.113(3.593-5.942) \mathrm{U}$ & $<0.001 \mathrm{U}$ & $\mathrm{U}$ \\
\hline & Garcia-Donas, 2011 & GG vs CC & $1.12(0.68-1.85) \mathrm{M}$ & $0.66 \mathrm{M}$ & $1.36(0.71-2.59) \mathrm{M}$ & $0.35 \mathrm{M}$ & M \\
\hline \multirow[t]{3}{*}{$\begin{array}{c}\text { VEGFR3 } \\
\mathrm{rs} 307821(\mathrm{G}>\mathrm{T})\end{array}$} & Dornbusch, 2016 & $\mathrm{TT}+\mathrm{TG}$ vs GG & $\begin{array}{l}1.351(0.388-4.707) \mathrm{M} \\
0.722(0.438-1.190) \mathrm{U}\end{array}$ & $\begin{array}{l}0.636 \mathrm{M} \\
0.201 \mathrm{U}\end{array}$ & $\begin{array}{l}1.349(0.226-8.066) \mathrm{M} \\
1.239(0.637-2.408) \mathrm{U}\end{array}$ & $0.743 \mathrm{M} 0.528 \mathrm{U}$ & $\mathrm{M} / \mathrm{U}$ \\
\hline & Beuselinck, 2013 & $\mathrm{TT}+\mathrm{TG}$ vs GG & $1.981(1.060-3.702) \mathrm{M}$ & $0.032 \mathrm{M}$ & $2.265(1.202-4.268) \mathrm{M}$ & $0.011 \mathrm{M}$ & M \\
\hline & Garcia-Donas, 2011 & TT vs GG & $3.31(1.64-6.68) \mathrm{M}$ & $0.014 \mathrm{M}$ & $1.24(0.41-3.75) \mathrm{M}$ & $0.71 \mathrm{M}$ & $\mathrm{M}$ \\
\hline
\end{tabular}

The source of HR and $95 \% \mathrm{CI}$ was extracted from survival curves or article reports.

HRs, hazard ratios; $95 \%$ CI, $95 \%$ confidence interval; M, multivariate analysis; $\mathrm{U}$, univariate analysis.

SNPs, single-nucleotide polymorphisms; VEGFA, vascular endothelial growth factor A; VEGFR, vascular endothelial growth factor receptor; OS, overall survival; PFS, progression-free survival.

A

Overall survival

Study VEGFR1 rs9582036 AA+AC vSCC

10

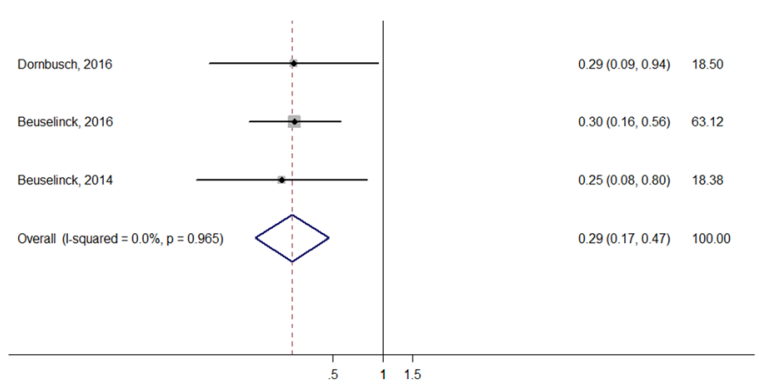

B

Overall survival
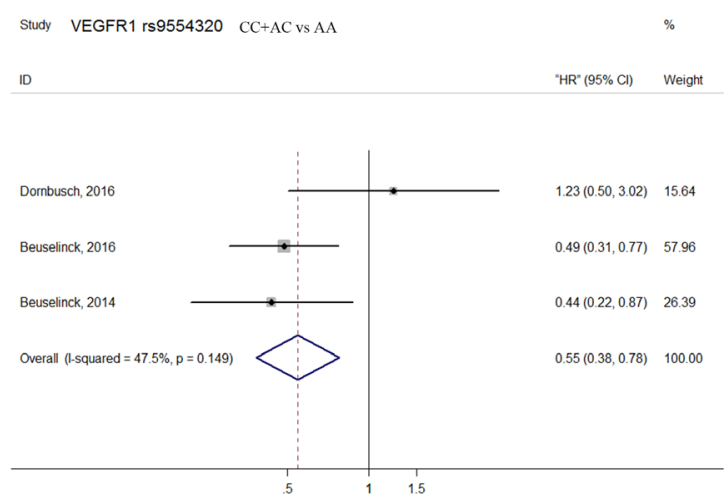

Figure 1: Forest plots of combined analyses associated with VEGFR1 polymorphisms. (A): OS with VEGFR1 rs9582036 (AA+AC vs CC); (B): OS with VEGFR1 rs9554320 (CC+AC vs AA). 


\section{DISCUSSION}

Sunitinib, as one of orally multiple tyrosine kinase inhibitors (mTKIs), has been approved by FDA in 2006 and widely used as the regular therapy for patients with mRCC $[27,28]$. It was suggested that the median PFS period has improved extraordinarily from 5 months with interferon-alpha to 11 months with sunitinib [23]. Approximately up to $47 \%$ of RCC patients experienced an objective response and $43 \%$ disease stabilization after sunitinib receiving [29]. To a certain degree, targeting angiogenetic pathway with sunitinib could bring about a complete disease alleviation and prolonged $\mathrm{mRCC}$ survival. However, during the sunitinib treatment period, PFS and OS of mRCC patients widely ranged from several weeks to years, which might not be easily linked with previous prognostic factors [30]. A growing body of evidence have illuminated that SNPs in several biomarkers including VEGF, VEGFR, STAT3 and interleukin (IL)-8 might be predictive parameters for TKIs therapy [31-33]. Several studies indicated the effects of genetic variability in these biomarkers on sunitinib outcome of mRCC patients might be contributed by the pharmacokinetics and pharmacodynamics of sunitinib. Among these mechanisms, SNPs in VEGF pathway owned the most robust clinical evidence, and had been described to involve in sunitinib outcome in mRCC patients [10, 16, 34, 35].

VEGF family consisting of five members: VEGF A, $\mathrm{B}, \mathrm{C}, \mathrm{D}$ and placental growth factor (PLGF), are secreted, dimeric glycoproteins and binding to specific VEGF receptors [36-39]. Studies have suggested that VEGF was aberrantly expressed in RCC, which highlighted that RCC was a VEGF-regulated tumor directly connected
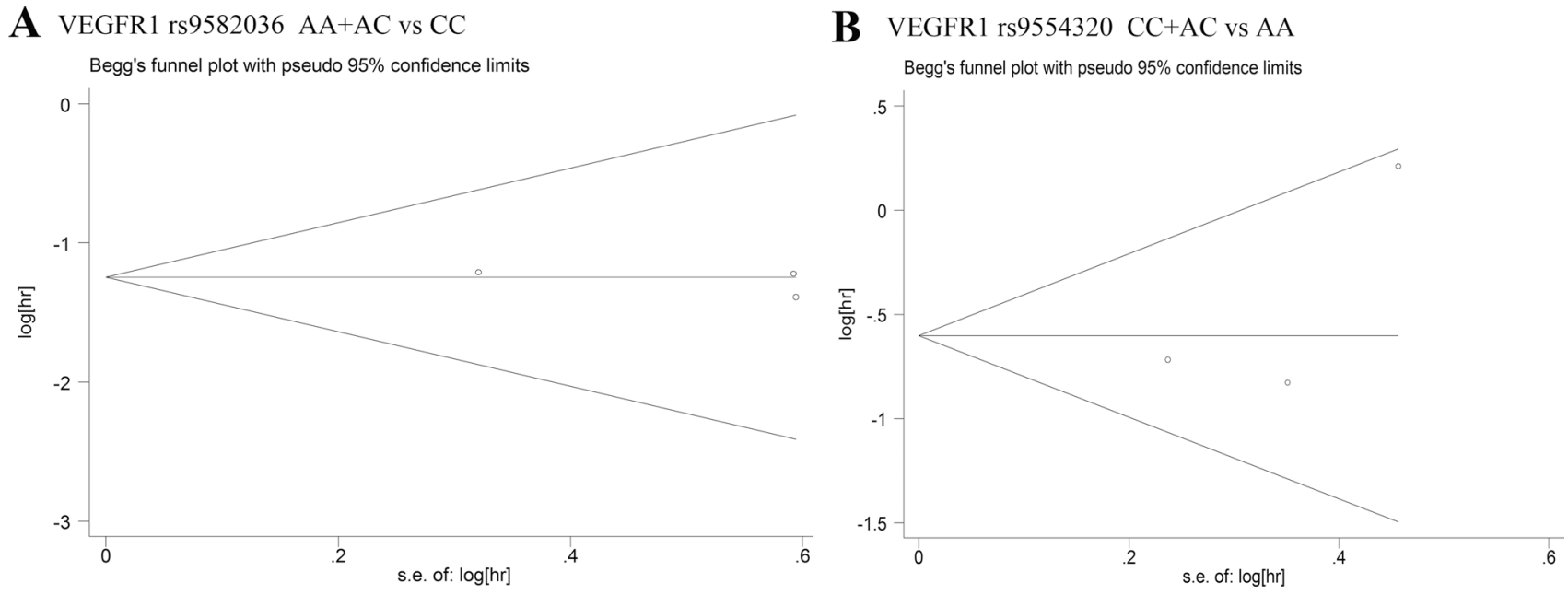

Figure 2: Begg's funnel plots of publication bias test. (A): OS with VEGFRI rs9582036 (AA+AC vs CC); (B): OS with VEGFRI rs9554320 (CC+AC vs AA).

A VEGFR1 rs9582036 AA+AC vs CC

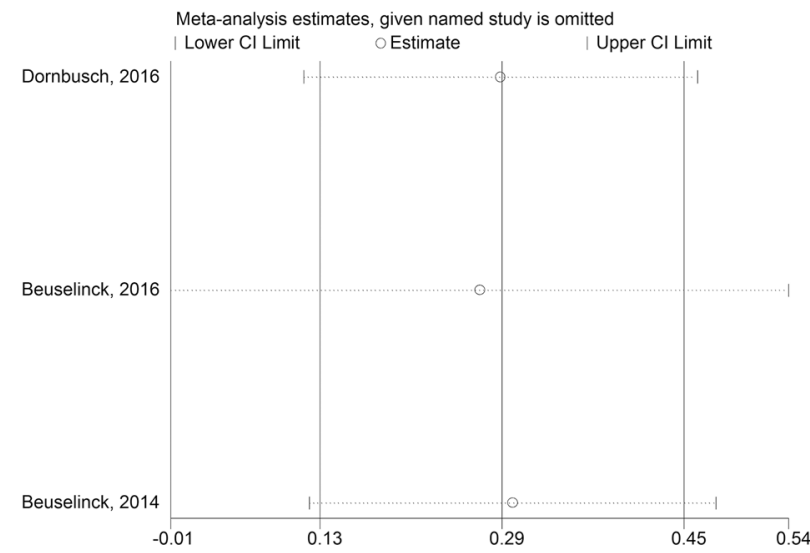

B VEGFR1 rs9554320 $\mathrm{CC}+\mathrm{AC}$ vs AA

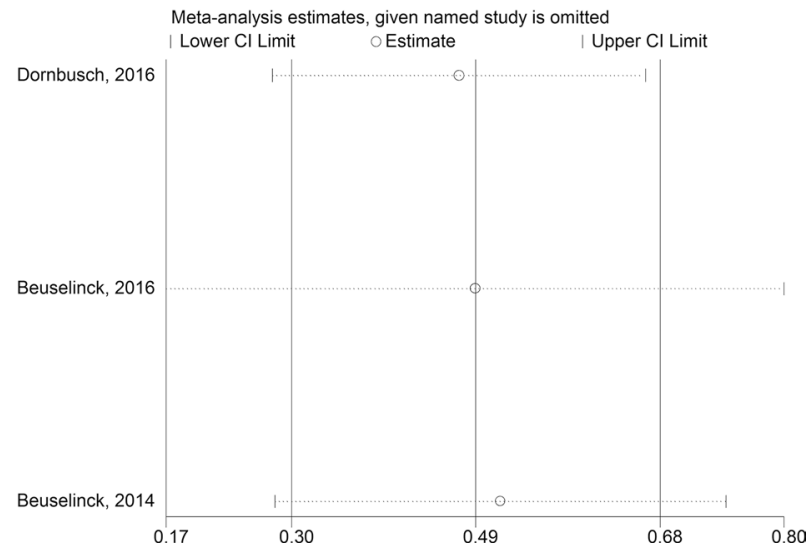

Figure 3: Sensitivity analysis under specific model. (A): effect of individual studies on the combined HR for OS with VEGFRI rs9582036 (AA+AC vs CC); (B): effect of individual studies on the combined HR for OS with VEGFR1 rs9554320 (CC+AC vs AA). 
with the expression levels of VEGF [40]. Changes in VEGF expression have been reported to be contributed by certain SNPs [30]. Different SNPs in VEGF gene may influence its circulating levels, and thus affect its effectiveness response to anti-VEGF therapy. Certain constitutive variation in VEGF and VEGFR expression levels could contribute to a significant difference in RCC outcome during antiangiogenetic treatment. In addition, it was suggested that RCC tumor vasculogenesis has also been associated with the SNPs in VEGF and $V E G F R$ genes through different biological mechanisms. As a antiangiogenetic drug directly targeting VEGF and VEGFR, sunitinib has been reported to involve in the effect of selected genetic variability on pharmacokinetics and pharmacodynamics in patients with mRCC. SNPs in genes of angiogenesis (VEGFA, VEGFR1, VEGFR2, VEGFR3) as well as gene involved in VEGF-independent pathways were investigated and confirmed to be related to sunitinib metabolism process in $\mathrm{mRCC}$ patients [14, 16, 17, 41]. Therefore, different prognosis induced by sunitinib in mRCC patients may be partially ascribed to the vascular pathways mediated by specific $V E G F$ and $V E G F R$ polymorphisms. Furthermore, accumulating studies have confirmed the association between the survival of patients and the occurrence of SNPs in $V E G F$ and VEGFR genes, but the results were inconsistent and controversial [13-15]. The predictive role of VEGF and VEGFR polymorphisms in $\mathrm{mRCC}$ prognosis remains unclear.

This systematic review and meta-analysis firstly assessed the correlation of $V E G F$ and $V E G F R$ polymorphisms with sunitinib-treated outcomes in $\mathrm{mRCC}$ patients. Sensitivity and heterogeneity analyses were also conducted to evaluate the stability of conclusion of enrolled studies. Our meta-analysis found that AA/AC in VEGFR1 rs9582036 predicted longer sunitinib OS (HR: 0.29, 95\% CI: 0.17-0.47), and rs9554320 with CC/AC carriers was correlated with more favorable OS (HR: 0.55, 95\% CI: 0.38-0.78) [13-15]. However, attributed to the limitation of study numbers, the pooled PFS analyses of these two sites were not carried out. So far, since the unified results were obtained between rs9582036, rs9554320 and patients OS with sunitinib, there was no need for subgroup analysis.

In addition, in three studies investigating VEGFA polymorphisms, Scartozzi et al. in 2013 found that patients with rs2010963 GG obtained more favorable PFS when compared with $\mathrm{CG} / \mathrm{CC}$ carriers [17]. Concerning VEGFA rs699947 and rs1570360, only Dornbusch's study described a statistically correlation between rs699947 and

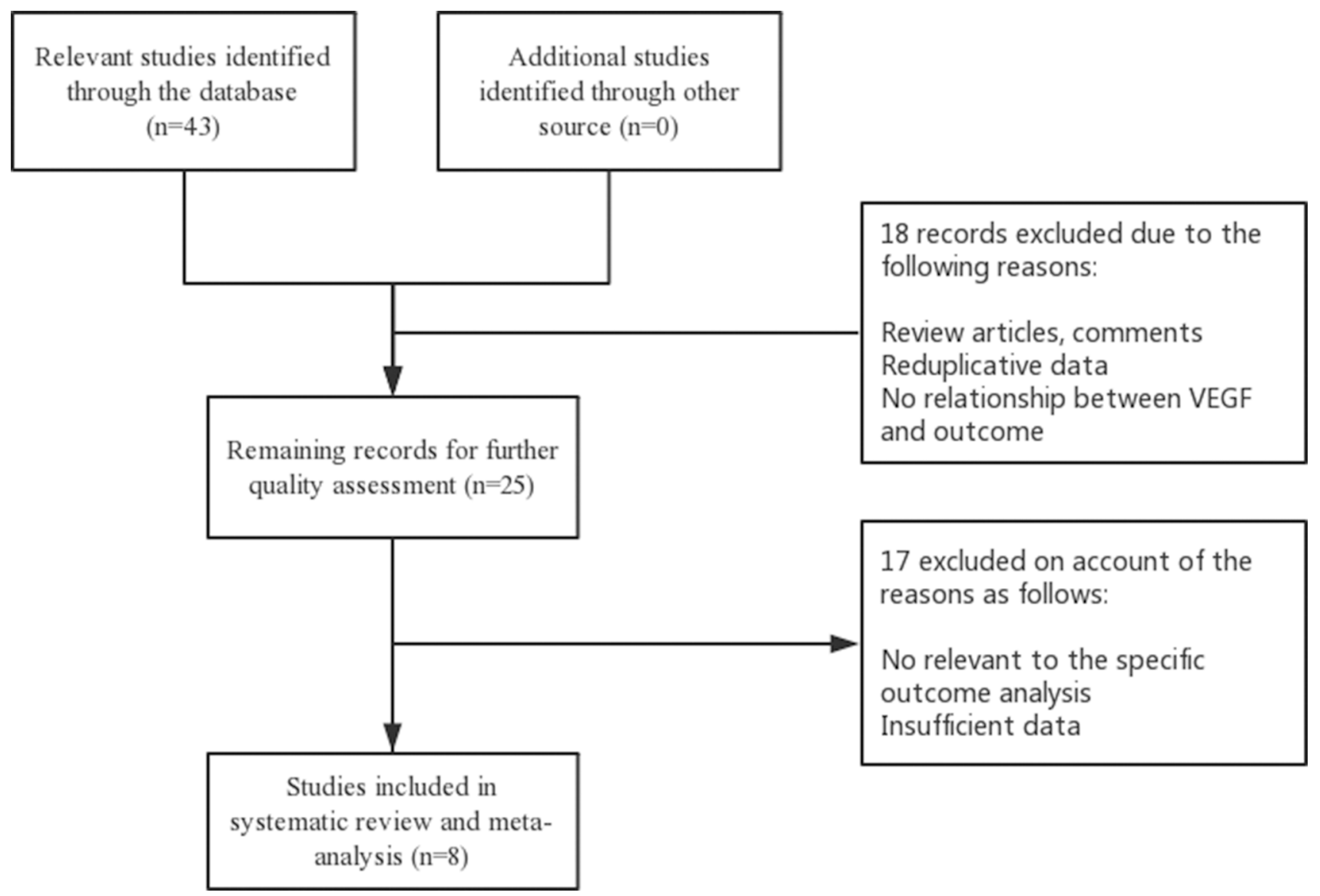

Figure 4: Flow diagram of the study selection process. 
PFS in univariate analysis but not in multivariate analysis, while others failed to make sense [15-17]. Associations of VEGFA polymorphisms in sunitinib outcome were not presented in forest plots by meta-analysis, which was mainly attributed to the limitation of research amounts. Therefore, the results ought to be corrected by further multiple findings. As it came to the effects of VEGFR2 and VEGFR3 polymorphisms, only individual studies found their correlation between SNPs and patients prognosis including OS and PFS, which could not be analyzed by statistical methods due to not only the limited investigations, but also differences in genotypes and analyzing models. Thus, associations between VEGFR2, VEGFR3 polymorphisms and $\mathrm{mRCC}$ outcomes should be promoted by further evidence.

Admittedly, our systematic review and metaanalysis still has the following deficiencies. Firstly, all studies included were English native, which might contribute to the language bias in results. Secondly, only 8 eligible studies concerning $V E G F$ and $V E G F R$ polymorphisms and sunitinib outcomes were included in this study, inducing our results might not be adequately persuasive. Further powerful clinical studies are required for more comprehensive conclusion. In addition, only one Asian study was applicable, which might create possible bias to some extent. Regarding these limitations, the potential value of $V E G F$ and $V E G F R$ polymorphisms in mRCC outcomes might be overly evaluated. Therefore, further large-scale and high-quality studies are needed to verify the associations.

In summary, this study suggested that $V E G F$ and $V E G F R$ polymorphisms could predict the prognosis of $\mathrm{mRCC}$ patients treated with sunitinib, especially VEGFR 1 polymorphisms. Nevertheless, in view of the insufficient data, more subsequent studies on larger cohorts of patients are required to evaluate former findings and to make a validation of the associations between VEGF family and the outcome of sunitinib-treated $\mathrm{mRCC}$ patients.

\section{MATERIALS AND METHODS}

\section{Search strategy}

We searched the relevant papers on PubMed, EMBASE and Web of Science and identified them manually. The keywords we used to search were: "VEGF or VEGFR or single nucleotide or gene" and "renal cell carcinoma or RCC" and "polymorphism" and "sunitinib". The last search date was June, 2017. The reference lists of included studies were manually checked for additional publications. A flow diagram of the study selection process is presented in Figure 4.

\section{Eligibility criteria}

Only original articles that focus on the association between $V E G F$ and $V E G F R$ polymorphisms and outcome in patients with metastatic renal cell carcinoma treated with sunitinib were eligible for our study. Publication language or date was not limited. Additionally, the exclusion criteria were as follows: (1) Studies concentrating on no prognosis in sunitinib treated mRCC. (2) Duplicated data in eligible studies.

\section{Data extraction}

Available data involved in eligible studies were extracted independently by two investigators (Miao CK and Wang YH). The extracted elements were recorded as the following: first author, publication year, main ethnicity, sample size, gender, gene SNPs, genotyping method, site of metastasis, survival analysis, source of HR and follow-up duration. Moreover, the relevant information of association between $V E G F / V E G F R$ polymorphisms and sunitinib-induced outcome was extracted from enrolled investigations by multivariate or univariate logistic regression analysis. The screened survival indexes consisted of PFS and OS of mRCC patients.

\section{Statistical analysis}

To test the heterogeneity of pooled HRs, Cochran's Q-test and Higgins $I^{2}$ statistics $\left(I^{2}\right)$ were performed in the meta-analysis. A fixed-effects model (Mantel-Haenszel method) or random-effects model (DerSimonian-Laird method) was conducted according to the heterogeneity of eligible data. When $P>0.05$ or the percentage of $I^{2}$ was lower than $75 \%$, a fixed-effects model was used to analyze the combined HR, otherwise a random-effects model was utilized. Begg's and Egger's test were utilized to detect the publication bias [42, 43]. Stata 12.0 (Stata Corporation, College Station, TX, USA) was used to calculate all statistical analyses.

\section{ACKNOWLEDGEMENTS}

The study was supported by National Natural Science Foundation of China (grant numbers 81270685), Qing Lan Project of Jiangsu University, A Project Funded by the Priority Academic Program Development of Jiangsu Higher Education Institutions (JX10231802), and Project of Nanjing Science and Technology Committee (201605001).

\section{CONFLICTS OF INTEREST}

The authors declare no conflicts of interests.

\section{REFERENCES}

1. Rini BI, Campbell SC, Escudier B. Renal cell carcinoma. Lancet. 2009; 373:1119-1132.

2. Gupta K, Miller JD, Li JZ, Russell MW, Charbonneau C. Epidemiologic and socioeconomic burden of metastatic renal cell carcinoma ( $\mathrm{mRCC})$ : a literature review. Cancer Treat Rev. 2008; 34:193-205. 
3. Blanco AI, Teh BS, Amato RJ. Role of radiation therapy in the management of renal cell cancer. Cancers (Basel). 2011; 3:4010-4023.

4. Godley P, Kim SW. Renal cell carcinoma. Curr Opin Oncol. 2002; 14:280-285.

5. Hartmann JT, Bokemeyer C. Chemotherapy for renal cell carcinoma. Anticancer Res. 1999; 19:1541-43.

6. Yamamoto K, Shinomiya K, Ioroi T, Hirata S, Harada K, Suno M, Nishioka T, Kume M, Makimoto H, Nakagawa T, Hirano T, Bito T, Nishigori C, et al. Association of Single Nucleotide Polymorphisms in STAT3 with Hand-Foot Skin Reactions in Patients with Metastatic Renal Cell Carcinoma Treated with Multiple Tyrosine Kinase Inhibitors: A Retrospective Analysis in Japanese Patients. Target Oncol. 2016; 11:93-99.

7. Ljungberg $\mathrm{B}$, Bensalah $\mathrm{K}$, Canfield $\mathrm{S}$, Dabestani $\mathrm{S}$, Hofmann F, Hora M, Kuczyk MA, Lam T, Marconi L, Merseburger AS, Mulders P, Powles T, Staehler M, et al. EAU guidelines on renal cell carcinoma: 2014 update. Eur Urol. 2015; 67:913-924.

8. Vakkalanka BK, Bukowski RM. Novel drugs for renal cell carcinoma. Expert Opin Investig Drugs. 2008; 17:1501-1516.

9. Ravaud A, Motzer RJ, Pandha HS, George DJ, Pantuck AJ, Patel A, Chang YH, Escudier B, Donskov F, Magheli A, Carteni G, Laguerre B, Tomczak P, et al, and S-TRAC Investigators. Adjuvant sunitinib in high-risk renalcell carcinoma after nephrectomy. N Engl J Med. 2016; 375:2246-54.

10. van Erp NP1, Eechoute K, van der Veldt AA, Haanen JB, Reyners AK, Mathijssen RH, Boven E, van der Straaten T, Baak-Pablo RF, Wessels JA, Guchelaar HJ, Gelderblom H. Pharmacogenetic pathway analysis for determination of sunitinib-induced toxicity. J Clin Oncol. 2009; 27:4406-4412.

11. Miao C, Xu A, Zheng Y, Liang C, Zhu J, Tian Y, Ma B, Lu P, Xu W, Li X. Association of STAT3 polymorphism with tyrosine kinase inhibitors-induced safety and efficacy in patients with metastatic renal cell carcinoma: a systematic review. AME Med J. 2017; 2:69.

12. Zheng Y, Zhang C, Miao C, Lu P, Ma B, Si S, Xu W, Wang J, Li X. ABCG2 rs2231142 polymorphism is related to sunitinib-induced toxicity in metastatic renal cell carcinoma: a systematic review. AME Med J. 2017; 2:78.

13. Beuselinck B, Jean-Baptiste J, Schöffski P, Couchy G, Meiller C, Rolland F, Allory Y, Joniau S, Verkarre V, Elaidi R, Lerut E, Roskams T, Patard JJ, et al. Validation of VEGFR1 rs9582036 as predictive biomarker in metastatic clear-cell renal cell carcinoma patients treated with sunitinib. BJU Int. 2016; 118:890-901.

14. Beuselinck B, Karadimou A, Lambrechts D, Claes B, Wolter P, Couchy G, Berkers J, van Poppel H, Paridaens R, Schöffski P, Méjean A, Verkarre V, Lerut E, et al. VEGFR1 single nucleotide polymorphisms associated with outcome in patients with metastatic renal cell carcinoma treated with sunitinib: a multicentric retrospective analysis. Acta Oncol. 2014; 53:103-112.
15. Dornbusch J, Walter M, Gottschalk A, Obaje A, Junker K, Ohlmann CH, Meinhardt M, Zacharis A, Zastrow S, Schoffer O, Grimm MO, Klug SJ, Wirth MP, et al. Evaluation of polymorphisms in angiogenesis-related genes as predictive and prognostic markers for sunitinib-treated metastatic renal cell carcinoma patients. J Cancer Res Clin Oncol. 2016; 142:1171-82.

16. Garcia-Donas J, Esteban E, Leandro-García LJ, Castellano DE, del Alba AG, Climent MA, Arranz JA, Gallardo E, Puente J, Bellmunt J, Mellado B, Martínez E, Moreno F, et al. Single nucleotide polymorphism associations with response and toxic effects in patients with advanced renal-cell carcinoma treated with first-line sunitinib: a multicentre, observational, prospective study. Lancet Oncol. 2011; 12:1143-1150.

17. Scartozzi M, Bianconi M, Faloppi L, Loretelli C, Bittoni A, Del Prete M, Giampieri R, Maccaroni E, Nicoletti S, Burattini L, Minardi D, Muzzonigro G, Montironi R, et al. VEGF and VEGFR polymorphisms affect clinical outcome in advanced renal cell carcinoma patients receiving first-line sunitinib. Br J Cancer. 2013; 108:1126-1132.

18. Ferrara N. Vascular endothelial growth factor. Arterioscler Thromb Vasc Biol. 2009; 29:789-791.

19. Ferrara N, Davis-Smyth T. The biology of vascular endothelial growth factor. Endocr Rev. 1997; 18:4-25.

20. Banumathy G, Cairns P. Signaling pathways in renal cell carcinoma. Cancer Biol Ther. 2010; 10:658-664.

21. Motzer RJ, Murphy BA, Bacik J, Schwartz LH, Nanus DM, Mariani T, Loehrer P, Wilding G, Fairclough DL, Cella D, Mazumdar M. Phase III trial of interferon alfa-2a with or without 13-cis-retinoic acid for patients with advanced renal cell carcinoma. J Clin Oncol. 2000; 18:2972-2980.

22. Lam JS, Leppert JT, Belldegrun AS, Figlin RA. Novel approaches in the therapy of metastatic renal cell carcinoma. World J Urol. 2005; 23:202-212.

23. Motzer RJ, Hutson TE, Tomczak P, Michaelson MD, Bukowski RM, Rixe O, Oudard S, Negrier S, Szczylik C, Kim ST, Chen I, Bycott PW, Baum CM, et al. Sunitinib versus interferon alfa in metastatic renal-cell carcinoma. $\mathrm{N}$ Engl J Med. 2007; 356:115-124.

24. Liu R, Wang X, Li W, Shou T, Zhou L, Li Y, Bai M, Pei Q. Influence of VEGFR single nucleotide polymorphisms on the efficacy of sunitinib therapy against renal cell carcinoma. Oncol Lett. 2017; 13:201-205.

25. Beuselinck B, Karadimou A, Lambrechts D, Claes B, Wolter P, Couchy G, Berkers J, Paridaens R, Schöffski P, Méjean A, Verkarre V, Lerut E, de la Taille A, et al. Singlenucleotide polymorphisms associated with outcome in metastatic renal cell carcinoma treated with sunitinib. Br J Cancer. 2013; 108:887-900.

26. Motzer RJ, Hutson TE, Hudes GR, Figlin RA, Martini JF, English PA, Huang X, Valota O, Williams JA. Investigation of novel circulating proteins, germ line single-nucleotide polymorphisms, and molecular tumor markers as potential efficacy biomarkers of first-line sunitinib therapy for 
advanced renal cell carcinoma. Cancer Chemother Pharmacol. 2014; 74:739-750.

27. Afriansyah A, Hamid AR, Mochtar CA, Umbas R. Targeted Therapy for Metastatic Renal Cell Carcinoma. Acta Med Indones. 2016; 48:335-47.

28. Roskoski R. Vascular endothelial growth factor (VEGF) and VEGF receptor inhibitors in the treatment of renal cell carcinomas. Pharmacol Res. 2017; 120:116-132.

29. Motzer RJ, Hutson TE, Tomczak P, Michaelson MD, Bukowski RM, Oudard S, Negrier S, Szczylik C, Pili R, Bjarnason GA, Garcia-del-Muro X, Sosman JA, Solska E, et al. Overall survival and updated results for sunitinib compared with interferon alfa in patients with metastatic renal cell carcinoma. J Clin Oncol. 2009; 27:3584-90.

30. Pander J, Gelderblom H, Guchelaar HJ. Pharmacogenetics of EGFR and VEGF inhibition. Drug Discov Today. 2007; 12:1054-1060.

31. Low SK, Fukunaga K, Takahashi A, Matsuda K, Hongo F, Nakanishi H, Kitamura H, Inoue T, Kato Y, Tomita Y, Fukasawa S, Tanaka T, Nishimura K, et al. Association study of a functional variant on ABCG2 gene with sunitinibinduced severe adverse drug reaction. PLoS One. 2016; 11:e0148177.

32. Watanabe A, Yamamoto K, Ioroi T, Hirata S, Harada K, Miyake H, Fujisawa M, Nakagawa T, Yano I, Hirai M. Association of Single Nucleotide Polymorphisms in STAT3, $\mathrm{ABCB} 1$, and ABCG2 with Stomatitis in Patients with Metastatic Renal Cell Carcinoma Treated with Sunitinib: A Retrospective Analysis in Japanese Patients. Biol Pharm Bull. 2017; 40:458-64.

33. Yamamoto K, Mizumoto A, Nishimura K, Uda A, Mukai A, Yamashita K, Kume M, Makimoto H, Bito T, Nishigori C, Nakagawa T, Hirano T, Hirai M. Association of toxicity of sorafenib and sunitinib for human keratinocytes with inhibition of signal transduction and activator of transcription 3 (STAT3). PLoS One. 2014; 9:e102110.

34. Eechoute K, van der Veldt AA, Oosting S, Kappers MH, Wessels JA, Gelderblom H, Guchelaar HJ, Reyners AK, van Herpen CM, Haanen JB, Mathijssen RH, Boven E. Polymorphisms in endothelial nitric oxide synthase (eNOS) and vascular endothelial growth factor (VEGF) predict sunitinib-induced hypertension. Clin Pharmacol Ther. 2012; 92:503-10.
35. Kim JJ, Vaziri SA, Rini BI, Elson P, Garcia JA, Wirka R, Dreicer R, Ganapathi MK, Ganapathi R. Association of VEGF and VEGFR2 single nucleotide polymorphisms with hypertension and clinical outcome in metastatic clear cell renal cell carcinoma patients treated with sunitinib. Cancer. 2012; 118:1946-1954.

36. Valtola R, Salven P, Heikkilä P, Taipale J, Joensuu H, Rehn M, Pihlajaniemi T, Weich H, deWaal R, Alitalo $\mathrm{K}$. VEGFR-3 and its ligand VEGF-C are associated with angiogenesis in breast cancer. Am J Pathol. 1999; 154:1381-1390.

37. Jia H, Bagherzadeh A, Bicknell R, Duchen MR, Liu D, Zachary I. Vascular endothelial growth factor (VEGF)-D and VEGF-A differentially regulate KDR-mediated signaling and biological function in vascular endothelial cells. J Biol Chem. 2004; 279:36148-36157.

38. Rini BI, Michaelson MD, Rosenberg JE, Bukowski RM, Sosman JA, Stadler WM, Hutson TE, Margolin K, Harmon CS, DePrimo SE, Kim ST, Chen I, George DJ. Antitumor activity and biomarker analysis of sunitinib in patients with bevacizumab-refractory metastatic renal cell carcinoma. J Clin Oncol. 2008; 26:3743-3748.

39. Stuttfeld E, Ballmer-Hofer K. Structure and function of VEGF receptors. IUBMB Life. 2009; 61:915-922.

40. Jacobsen J, Grankvist K, Rasmuson T, Bergh A, Landberg G, Ljungberg B. Expression of vascular endothelial growth factor protein in human renal cell carcinoma. BJU Int. 2004; 93:297-302.

41. van der Veldt AA, Eechoute K, Gelderblom H, Gietema J, Guchelaar HJ, van Erp NP, van den Eertwegh AJ, Haanen JB, Mathijssen RH, Wessels JA. Genetic polymorphisms associated with a prolonged progression-free survival in patients with metastatic renal cell cancer treated with sunitinib. Clin Cancer Res. 2011; 17:620-29.

42. Egger M, Smith GD. Bias in location and selection of studies. BMJ. 1998; 316:61-66.

43. Egger M, Davey Smith G, Schneider M, Minder C. Bias in meta-analysis detected by a simple, graphical test. BMJ. 1997; 315:629-34. 